\title{
ARTICLE
}

\section{Biological control of rice sheath blight disease with formu- lation of indigenous Trichoderma strains under paddy field conditions}

\author{
Shahram Naeimi ${ }^{1}$, Vahid Khosravi ${ }^{2}$, Mohammad-Zaman Nouri ${ }^{2}$, Hassan Hoda ${ }^{1}$, Csaba \\ Vágvölgyi³, László Kredics ${ }^{3 *}$

\begin{abstract}
'Department of Biological Control Research, Iranian Research Institute of Plant Protection, Agricultural Research Education and Extension Organization, Tehran 19395, Iran

${ }^{2}$ Rice Research Institute of Iran, Mazandaran Branch, Agricultural Research Education and Extension Organization, Amol 46191-91951, Iran

${ }^{3}$ Department of Microbiology, Faculty of Science and Informatics, University of Szeged, Szeged, Hungary
\end{abstract}

\begin{abstract}
The effectiveness of indigenous Trichoderma strains in preventing sheath blight disease was evaluated during two growing seasons under paddy field conditions. Broom sorghum seeds were used for mass production of Trichoderma strains. Colonized seeds were ground to powder and mixed with talc and carboxymethyl cellulose. Suspensions were made from the bioformulations and sprayed onto rice plants. Effects of Trichoderma strains on disease incidence and severity as well as yield and other growth parameters were determined and compared with a chemical fungicide and a commercial biofungicide. A combined analysis of variance across two years was performed and a statistically significant effect of year, treatment and their interaction was reported. Results indicate that environmental factors and different biological fungicides had a strong effect on disease development under natural conditions. According to the results, propiconazole and T. harzianum AS12-2 resulted in the least disease severity and incidence. Overall, the efficacy of T. harzianum AS12-2 in reducing sheath blight development was significantly better than other Trichoderma treatments and was comparable to the conventional fungicide.

Acta Biol Szeged 63(3):37-43 (2019)
\end{abstract}

\section{Introduction}

Rice (Oryza sativa L.) is the staple food crop of over half of the world's population living mainly in Asia (Qin and Zhang 2005). Sheath blight of rice caused by Rhizoctonia solani Kühn AG1-IA is a very destructive disease of high-yielding varieties under favorable conditions for the pathogen. This disease is widely spread in most of the rice growing areas of the world and causes considerable yield losses (Ou 1985). Chemical fungicides are primarily used for sheath blight control (Rabindran and Vidhyasekaran 1996), but management of the disease is difficult because $R$. solani survives in soil as sclerotia and in rice plant tissues as mycelia (Jayaprakashvel et al. 2010). However, the application of chemical fungicides has several disadvantages, such as the development of resistance in the pathogen, phytotoxicity, toxic effects on human health, pollution of the environment, high costs and loss of biodiversity (Groth et al. 1990; Sehajpal et al. 2009). Therefore, considering the negative impacts due to indiscriminate use of synthetic pesticides, it has become necessary to adopt ecofriendly approaches to avoid environmental pollution and ensure better crop management. Biological control using microbial biopesticides provides an attractive and environmentally safe alternative to chemical fungicides in the management of rice sheath blight (Mew and Rosales 1986; Vasantha Devi et al. 1989). The application of beneficial microorganisms in agriculture has recently become more important and several commercial biopesticides and biofertilizers are already on the market (Kumar et al. 2014).

Fungi belonging to the genus Trichoderma are ubiquitous over wide geographic areas of the world with the broadest impact on mankind (Kredics et al. 2014). Among the fungal biocontrol agents, Trichoderma spp. are the most promising in controlling foliar and root diseases of several crops (Elad 2000; Mathivanan et al. 2004). At present, several commercial formulations of Trichoderma are available worldwide as biopesticides, biofertilizers, growth enhancers and stimulants of natural resistance. Due to changing of the public viewpoint on consumption 
of chemical-free food and protecting the environment, use of Trichoderma-based products can be expected to increase in the future (Woo et al. 2014).

Several Trichoderma isolates showed good potential in inhibiting $R$. solani AG-IA in vitro and in suppressing the sheath blight under greenhouse conditions (Roy 1977; Gokulapalan and Nair 1984; Cumagun and Lapis 1993; Khan and Sinha 2007; Naeimi et al. 2010, 2011; Chen et al. 2015), but their application for the control of the disease under natural conditions is limited (Nagaraju et al. 2002; Mathivanan et al. 2005; De França et al. 2015).

Many biocontrol agents (BCAs) have been found effective in inhibiting the growth of different plant pathogens under in vitro and greenhouse conditions, but they often fail to control the disease in fields and orchards (Alabouvette et al. 2006; Gerbore et al. 2014). Ecological factors, plant growth stages, the time and rate of application, the inoculum levels of the pathogen and the applied BCA, the diversity of the natural population of the pathogen, the method of delivery and other factors may affect the biological control efficacy in natural environments.

Before developing a biofungicide, production, formulation and application strategies need to be carefully studied (Burges 1998). In addition, the adaptation of a promising $\mathrm{BCA}$ to the agroecosystem and specific habitat in which it will be applied should primarily be evaluated (Ojiambo and Scherm 2006). In the case of rice sheath blight, the soil borne $R$. solani causes foliar damage, therefore the ideal BCA should survive in the phyllosphere (Chen et al. 2015) and the biocontrol success depends on the application and survival of antagonist populations at the target site (Savazzini et al. 2009).

In our previous study, several native Trichoderma isolates obtained from the paddy fields of northern Iran were screened against $R$. solani in vitro and their efficiencies in controlling rice sheath blight were evaluated under greenhouse conditions, where significant disease reduction was achieved (Naeimi et al. 2010). The present study was conducted to investigate the biocontrol efficacy of the four most effective strains as a talc-based powder formulation in preventing sheath blight disease development in field plots artificially infested with the pathogen over two successive years.

\section{Materials and Methods}

\section{Field design}

All trials were conducted in a paddy field located at the experimental farm of the Rice Research Institute of Iran, Amol, Mazandaran (36 28' 691" N | 52 27' 744" E, 30 $\mathrm{m}$ altitude), over two growing seasons (April-September 2012 and 2013). The field was divided into 24 plots; each with a size of $1 \times 2 \mathrm{~m}$, resulting in a total of $4 \times 8=32$ rice hills. Rice seedlings (Shiroodi, a susceptible, highyielding cultivar) were raised in the seedling bed for 25 days and transplanted in the main field with a spacing of $25 \mathrm{~cm}$ between and within rows. Agronomic practices followed state recommendations for rice production and the recommended dose of fertilizers (100:30:80 kg of $\mathrm{NPK} / \mathrm{ha}$ ) was applied to the field. No chemical pesticides were applied to the experimental plots unless otherwise mentioned. The crop was harvested at maturity and threshed to calculate crop yield. The study was continued in the same field with the same layout during the next growing season.

\section{Pathogen and biocontrol agents}

The fungal strains applied in this study are listed in Table 1 . A virulent strain of the sheath blight pathogen Rhizoctonia solani AG1-IA (RBL1) isolated from a naturally infected rice plant was used in all experiments. The Trichoderma strains used in this study (T. harzianum AS3-5, T. harzianum AS12-2, T. virens AD1-3 and T. virens AS16-22) had shown biocontrol activity against $R$. solani in vitro and suppressed the sheath blight incidence under glasshouse conditions in a previous study (Naeimi et al. 2010).

Table 1. Fungal strains applied during this study

\begin{tabular}{|c|c|c|c|c|}
\hline \multirow[t]{2}{*}{ Fungal strain } & \multirow[t]{2}{*}{ Habitat } & \multirow[t]{2}{*}{ Location } & \multicolumn{2}{|c|}{$\begin{array}{c}\text { GenBank accession } \\
\text { numbers }\end{array}$} \\
\hline & & & ITS & tef1a \\
\hline T. harzianum AS12-2 & Paddy soil & Chaloos & EU821789 & FJ618586 \\
\hline T. harzianum AS3-5 & Paddy soil & Amol & EU821780 & FJ618586 \\
\hline T. virens AD1-3 & Rice debris & Freydoonkenar & EU821794 & FJ618575 \\
\hline T. virens AS16-22 & Paddy soil & Sari & EU821795 & FJ618575 \\
\hline R. solani RBL1 & $\begin{array}{l}\text { Infected } \\
\text { sheath }\end{array}$ & Amol & HM211085 & $\mathrm{n} / \mathrm{a}$ \\
\hline
\end{tabular}

\section{Inoculum preparation of $R$. solani}

Five mycelial discs (5 $\mathrm{mm}$ in diameter) cut from the margin of 3-day-old culture of the pathogen ( $R$. solani strain RBL1) on potato dextrose agar medium (Merck, Germany) were inoculated into 2 L Erlenmeyer flasks containing $1 \mathrm{~kg}$ autoclaved rice husk and rice bran (1:1) and incubated at $28 \pm 1{ }^{\circ} \mathrm{C}$ for 30 days.

\section{Preparation of talc-based formulation of Trichoderma strains}

For mass production of Trichoderma strains, broom sor- 
ghum (Sorghum vulgare var. technicum) grains were soaked in water overnight. Then, $300 \mathrm{~g}$ of grains were filled in 1 L Erlenmeyer flasks and sterilized in an autoclave for 30 min in three successive days. After cooling the grains to room temperature, three mycelial discs $(5 \mathrm{~mm})$ cut from the edge of growing colonies of Trichoderma strains were aseptically transferred to the flasks, which were subsequently kept at ambient laboratory temperature $\left(26-32^{\circ} \mathrm{C}\right)$ for 30 days and periodically shaken in order to have uniform growth of BCAs. After this period, Trichoderma inocula were taken out from the flasks, air dried, ground to a powder with Mortar Grinder Pulverisette 2 (Fritsch, Germany) and mixed well with extra fine pure talc powder (Merck, Germany) and carboxymethyl cellulose (CMC; $\mathrm{BDH}$, England) as sticker at a 1:2:0.005 ratio under aseptic conditions. The mixture of talc and CMC was autoclaved for $30 \mathrm{~min}$ for two consecutive days before adding the BCAs. All formulations were packed in plastic containers, sealed and stored at room temperature until use. In the first year of the experiment, the populations of T. harzianum AS3-5, T. harzianum AS12-2, T. virens AD1-3 and T. virens AS16-22 in the formulation were $6 \times 10^{9}, 2.5 \times 10^{10}, 2.0$ $\times 10^{10}$ and $8.0 \times 10^{9} \mathrm{cfu} / \mathrm{g}$ of formulation, respectively at the time of application. Similarly, in the secon year the populations of these four strains were $6.1 \times 10^{9}, 2.5 \times 10^{10}$, $1.8 \times 10^{10}$ and $7.9 \times 10^{9} \mathrm{cfu} / \mathrm{g}$ of formulation, respectively.

\section{Pathogen inoculation and application of biocontrol agents}

To ensure uniform disease incidence and severity during both growing seasons, 40 days after transplanting at the maximum tillering stage of rice (one week after the first application of biocontrol formulation), $5 \mathrm{~g}$ of the prepared $R$. solani inoculum was placed among tillers in the centre of twelve rice hills per replication near the waterline (Tang et al. 2007).

Formulations of each native Trichoderma strain were dissolved in water, thoroughly mixed, filtered through two layers of cheesecloth (after $30 \mathrm{~min}$ ) and sprayed four times on rice foliage at $750 \mathrm{~L} / \mathrm{ha}$ as I) 7 days prior to pathogen inoculation; II) on the following day after inoculation of $R$. solani; III) 7 days and IV) 14 days after the second application. Tween 20 (Merck, Germany) at $0.05 \%$ was added to the suspensions as a surfactant before spraying. Trianum $\mathrm{P}$ (Koppert, the Netherlands), a commercial biofungicide which contains Trichoderma harzianum KRL-AG2 (T-22) $\left(1 \times 10^{9} \mathrm{cfu} / \mathrm{g}\right)$ was also applied as above on rice foliage as a comparative treatment according to the manufacturer's instruction. All BCAs were sprayed on the phyllosphere of rice with a $2 \mathrm{~L}$ hand sprayer (EVA, Dimartino, Italy) after sunset. Propiconazole (TILT ${ }^{\circledR}, 250$ EC, Syngenta, Switzerland) was used as the chemical fungicide control and applied as a foliar spray (1 L/ha) 2 days after inocula- tion. Plants inoculated only with $R$. solani were considered as inoculated control. Furthermore, for non-inoculated control, plants were sprayed with distilled water and no input (BCA and/or fungicide) was applied.

\section{Disease assessment}

Two weeks after artificial inoculation of the pathogen (AIP), 6 hills from each treatment per replication were randomly selected and tagged to observe the sheath blight incidence [in terms of the percentage of infected tillers (PIT)]. For assessing sheath blight severity, the relative lesion height (RLH) of 5 tillers from each 6 randomly selected hills was first calculated and then the disease severity was recorded according to the 0-9 scale of Standard Evaluation System developed by the International Rice Research Institute (IRRI 2002). The incidence and severity of sheath blight was also determined 35 days after AIP to see whether the formulations still had an effect on the prevention of disease development. Agronomic traits of rice including plant height $(\mathrm{PH})$, number of tillers/hill, crop yield and 1000-grains weight (GW) were measured.

\section{Meteorological data}

All climate data including air temperature, relative humidity $(\mathrm{RH})$, precipitation and sunlight hours were taken from Amol Weather Station located about $300 \mathrm{~m}$ from the experimental area.

\section{Statistical analysis}

All field experiments were established as a randomized complete block design with three replicates. A combined analysis of variance (ANOVA) was performed to determine the effect of year and treatments on disease development and agronomic traits, using the SAS software ver. 9.1.3 (SAS Institute, Cary, NC). All means of the treatments were compared by Duncan's multiple range tests at $P \leq 0.01$.

\section{Results}

Rice sheath blight severity and incidence were notably decreased in some BCA-treated plots under field conditions. The effect of year on $\mathrm{RLH}_{14}, \mathrm{PIT}_{14}, 1000 \mathrm{GW}$, plant height $(\mathrm{P} \leq 0.01)$ and No. of tillers $(\mathrm{P} \leq 0.05)$ proved to be significant according to the results of the combined analysis of variance for both years (Table 2). Disease severity (in terms of RLH) and incidence (in terms of PIT) after 14 days as well as growth parameters were lower for the second year. The effect of treatment on all characteristics except for plant height and No. of tillers was significant at $\mathrm{P} \leq 0.01$ (Table 2). In the case of traits with significant treatment $\times$ year interactions, including $\mathrm{RLH}_{14}, \mathrm{PIT}_{14}$ and $\mathrm{RLH}_{35}$, ANOVA was performed for each 
Naeimi et al.

Table 2. F-values for the effects of year, treatment and their interaction according to combined ANOVA over two years (2012-2013)

\begin{tabular}{llllllllll}
\hline \multirow{2}{*}{ Source of variation } & \multirow{2}{*}{ Degree of freedom } & \multicolumn{7}{c}{ F-value } \\
\cline { 3 - 8 } & & $\mathrm{RLH}_{14}$ & $\mathrm{RLH}_{35}$ & $\mathrm{PIT}_{14}$ & $\mathrm{PIT}_{35}$ & Yield & $1000 \mathrm{GW}$ & $\mathrm{PH}$ & No. of tillers \\
\hline Year & 1 & $40.21^{* *}$ & 1.14 & $28.6^{* *}$ & 0.61 & 5.31 & $308.9^{* *}$ & $99.74^{* *}$ & $16^{*}$ \\
Treatment & 7 & $21.03^{* *}$ & $17.19^{* *}$ & $19.56^{* *}$ & $17.31^{* *}$ & $6.13^{* *}$ & $4.63^{* *}$ & 0.93 & 2.2 \\
Treatment $\times$ Year & 7 & $5.05^{* *}$ & $2.57^{*}$ & $6.46^{* *}$ & 2.16 & 1.49 & 0.96 & 0.5 & 1.69 \\
\hline
\end{tabular}

$\mathrm{RLH}=$ relative lesion height, $\mathrm{PIT}=$ percentage of infected tillers, GW=grain weight, $\mathrm{PH}=$ plant height. * , **: Significant at 5 and $1 \%$, respectively.

growing season and means were compared using Duncan's multiple range test (Table 3). The minimum sheath blight incidence was recorded for propiconazole $\left(\mathrm{PIT}_{35}=\right.$ 57.01\%) and T. harzianum AS12-2 ( PIT $\left._{35}=60.67 \%\right) 35$ days after AIP $(\mathrm{P} \leq 0.01)$ (Fig. 1). Non-treated plots showed the highest yield (6433 kg/ha) and $1000-\mathrm{GW}(27.79 \mathrm{~g})$. It is important to note that agronomical characteristics were not significantly different among Trichoderma-treated and fungicide-treated plots (data not shown).

According to the first year data, 14 days after AIP, $T$. harzianum AS12-2 and propiconazole provided the lowest disease scores (2.55 and 2.78, respectively) (data not shown). The minimum $\mathrm{RLH}_{14}$ of 22.18 and 24.19 were recorded for T. harzianum AS12-2 and propiconazole, respectively, when compared to the inoculated control (Table 3). In addition, among the treatments, T. harzianum AS12-2 was found to be most effective in reducing disease incidence ( $\left.\mathrm{PIT}_{14}=36.35 \%\right)$, which was less than in the case of chemical fungicide-treated plots $\left(\mathrm{PIT}_{14}=\right.$ $72.27 \%$ ). Other treatments were not significantly different in terms of disease incidence 14 days after AIP. Trianum $\mathrm{P}$ led to the lowest reduction of disease severity $\left(\mathrm{RLH}_{14}\right.$ $=36.36 \%)$ and incidence $\left(\mathrm{PIT}_{14}=98.21 \%\right)$ compared to the native biocontrol agents. Thirty five days after AIP, the lowest disease scale (3.44) and $\mathrm{RLH}_{35}$ (27.87\%) were observed in propiconazole-treated plots. Formulation of native Trichoderma spp. together with Trianum P although not significantly different from the chemical fungicide - resulted in relatively higher disease severity ranging from $44.22 \%$ to $51.73 \%$ (Table 3 ).

In the second year of the experiment, T. harzianum AS3-5, propiconazole and T. harzianum AS12-2 showed the lowest disease scores 14 days after AIP, as compared to the control $\left(0.37,0.48\right.$ and 0.55 , respectively). The $\mathrm{RLH}_{14}$ values of the aformentioned treatments were $4.03 \%$, 4.85\% and $6.4 \%$, respectively, which were not significantly different (Table 3). These treatments also showed the minimum disease incidences ( $\mathrm{PIT}_{14}$ of $7.4 \%, 9.56 \%$ and $12.94 \%$, respectively) and were not significantly different from each other and from the non-inoculated control $\left(\mathrm{PIT}_{14}=\right.$ 5.87\%). Similar to the results of the first year, Trianum $P$ was the least effective in suppressing sheath blight $\left(\mathrm{RLH}_{14}\right.$ $=25.49 \%, \mathrm{PIT}_{14}=93.83 \%$ ). The lowest disease scales and RLH values were recorded for propiconazole (0.97 and 8.93\%, respectively), T. harzianum AS12-2 (3.54 and 13.5\%, respectively) and T. harzianum AS3-5 (3.84 and 30.27\%, respectively) 35 days after AIP.

Table 3. Effect of bioformulation of native Trichodema strains on sheath blight incidence (as percentage of infected tillers = PIT) and severity (as relative lesion height $=$ RLH) 14 and 35 days after artificial inoculation with Rhizoctonia solani in two successive years

\begin{tabular}{|c|c|c|c|c|c|c|}
\hline \multirow{2}{*}{ Treatment } & \multicolumn{2}{|c|}{$\mathrm{RLH}_{14}$} & \multicolumn{2}{|c|}{$\mathrm{RLH}_{35}$} & \multicolumn{2}{|c|}{$\mathrm{PIT}_{14}$} \\
\hline & 2012 & 2013 & 2012 & 2013 & 2012 & 2013 \\
\hline T. harzianum AS12-2 & $22.18 \pm 5.5 b$ & $6.4 \pm 2.2 \mathrm{bcd}$ & $50.18 \pm 14.3 a b$ & $29.73 \pm 7.5 \mathrm{ab}$ & $36.35 \pm 16.7 b$ & $12.94 \pm 6.8 b c$ \\
\hline T. harzianum AS3-5 & $31.28 \pm 2.2 \mathrm{ab}$ & $4.03 \pm 2.0 \mathrm{~cd}$ & $51.73 \pm 10.2 a b$ & $30.27 \pm 3.8 \mathrm{ab}$ & $94.79 \pm 6.5 a$ & $7.4 \pm 4.6 \mathrm{bc}$ \\
\hline T. virens AD1-3 & $30.10 \pm 7.1 \mathrm{ab}$ & $10.19 \pm 4.3 \mathrm{abcd}$ & $46.67 \pm 2.0 \mathrm{ab}$ & $58.1 \pm 5.3 a$ & $91.67 \pm 7.2 \mathrm{a}$ & $25.73 \pm 14.3 b c$ \\
\hline T. virens AS16-22 & $31.10 \pm 1.6 \mathrm{ab}$ & $22.57 \pm 7.7 \mathrm{abc}$ & $44.22 \pm 17.1 \mathrm{ab}$ & $61.63 \pm 0.8 a$ & $79.36 \pm 18 a$ & $58.85 \pm 20.9 a b$ \\
\hline Trianum $\mathrm{P}$ & $36.36 \pm 4.4 \mathrm{a}$ & $25.49 \pm 0.45 a b$ & $51.24 \pm 4.1 \mathrm{ab}$ & $44.94 \pm 3.3 \mathrm{a}$ & $98.21 \pm 1.5 \mathrm{a}$ & $93.83 \pm 5.4 \mathrm{a}$ \\
\hline Propiconazole & $24.19 \pm 4.9 b$ & $4.85 \pm 2.4 \mathrm{~cd}$ & $27.87 \pm 16.6 b$ & $8.93 \pm 4.2 b$ & $72.27 \pm 14.4 \mathrm{a}$ & $9.56 \pm 6.5 b c$ \\
\hline Inoculated control & $35.97 \pm 2.5 \mathrm{a}$ & $30.06 \pm 1.5 \mathrm{a}$ & $55.50 \pm 3.3 a$ & $48.07 \pm 4.8 \mathrm{a}$ & $98.1 \pm 2.5 \mathrm{a}$ & $99.57 \pm 0.7 a$ \\
\hline Non-inoculated control & $0.20 \pm 0.07 c$ & $2.86 \pm 1.4 \mathrm{~d}$ & $0.72 \pm 0.34 \mathrm{c}$ & $13.5 \pm 7.4 \mathrm{~b}$ & $1.52 \pm 1.1 \mathrm{c}$ & $5.87 \pm 3.4 c$ \\
\hline
\end{tabular}

Values (means $\pm \mathrm{SE}$ ) within a column followed by the same letter(s) are not significantly different according to the Duncan's multiple range test $(P=0.01)$ 


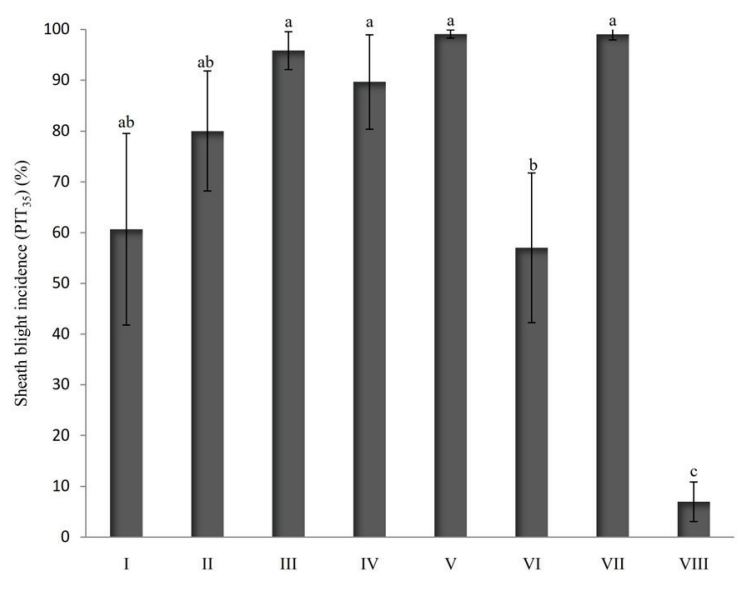

Figure 1. Effect of different treatments on sheath blight incidence (as percentage of infected tillers = PIT), 35 days after artificial inoculation with Rhizoctonia solani in two successive years.

I: Trichoderma harzianum AS12-2; II: T. harzianum AS3-5; III: T. virens AD1-3; IV: T. virens AS16-22; V: Biofungicide (Trianum P); VI: Chemical fungicide (propiconazole); VII: Inoculated control; VIII: Non-inoculated control. Values represented by the same letter(s) above the bars are not significantly different according to Duncan's multiple range test $(P=0.01)$. Each value represents the mean of three replicates.

\section{Discussion}

In order to commercialize a promising BCA as a microbial biopesticide, it has to be evaluated under the natural environmental conditions with a suitable formulation (Fravel and Larkin 1996; Alabouvette et al. 2006). In this study, four native Trichoderma strains were examined for prevention of the rice sheath blight disease and promotion of plant growth and grain yields under paddy field conditions. Application of talc-based formulations of some autochthonous Trichoderma strains significantly reduced the sheath blight severity and incidence caused by $R$. solani, which was comparable with the chemical fungicide propiconazole.

Although Shiroodi is a rice cultivar susceptible to sheath blight, the natural infection by the pathogen was very low in both years. On the other hand, the disease score recorded for inoculated control was not very high. This suggests that mild severity of sheath blight is probably related to environmental conditions. Optimum conditions for sheath blight infection and development are high temperature $\left(30-32^{\circ} \mathrm{C}\right)$, high $\mathrm{RH}(>95 \%)$ and shading (Ou 1985). Meteorological data indicate that temperature, $\mathrm{RH}$ and sunlight hours during AIP to the second disease evaluation were below the optimum conditions of infection and development of pathogen in the field.

Initially, some biocontrol agents demonstrated effective biocontrol properties, but for a longer period of time they were not able to satisfactorily suppress the disease. For instance, although T. harzianum AS12-2 promisingly controlled sheath blight, even better than the chemical fungicide at first, disease severity increased at the harvesting stage in the plots treated with this strain. This is consistent with findings of Perelló et al. (2009), who reported that although Trichoderma spp. effectively reduced the severity of Septoria blotch at the tillering stage of wheat, they failed to control the disease at the heading stage. It is speculated that despite four times of application of Trichoderma strains in the field, probably due to inappropriate environmental conditions, high microbial competitions and presumably other factors, they could not maintain or increase their populations and adopt to the rice phylloplane, therefore they failed to inhibit the disease development until the end of the season. Effective antagonists must become established in crop ecosystems and remain active against the target pathogens during the periods favorable for infection (Lo et al. 1998). Trichoderma strains are not common phyllosphere inhabitants (Elad and Kirshner 1993; Latorre et al. 1997), and if they are applied to above-ground plant parts, their populations may decrease by a factor of 10-100 within a period of 2 weeks (Freeman et al. 2004). According to the climate data for the time span between the first application of BCAs and the second disease assessment (40 days), the average air temperature was $28{ }^{\circ} \mathrm{C}$ in both years which favored the fungal BCAs. However, the limiting factor was very likely the RH and wetness time of the rice phyllosphere. The average $\mathrm{RH}$ values during the mentioned time in 2012 and 2013 were $55 \%$ and $61 \%$, respectively. Moreover, the average precipitation was less than $1 \mathrm{~mm}$ and $1.6 \mathrm{~mm}$, respectively. Many fungi, including Trichoderma strains need moisture for germination, growth and colonization, therefore the low moisture and dryness of the rice phylloplane may ultimately have negative effects on the antagonistic potential of the applied BCAs in the field. The average sunlight hours in the first and second year were 7 $\mathrm{h}$ and $8 \mathrm{~h}$, respectively. Direct exposure to solar radiation reduces conidial production, survival, germination, and can kill the conidia of most fungal species, which limits the size of the fungal population and reduces the efficacy of fungal BCAs (Braga et al. 2015). The deleterious effects of ultraviolet (UV) radiation on conidia have been demonstrated in several fungi including Trichoderma spp. (Moody et al. 1999; Stevenson and Weimer 2002). Solar UV may therefore have negatively affected the survival and biocontrol potential of native BCAs in the current study after field application. Under the aforementioned conditions, $R$. solani developed to panicles as well as neighboring tillers during the time between the two disease evaluations. This suggests that although native Trichoderma strains effectively suppressed the pathogen 
during the initial stage of disease development, but for an extended period of time, when environmental conditions are conducive to $R$. solani or the BCAs can not adapt to the rice phylloplane, sheath blight may eventually develop, although still at a slower and less severe rate. The high inoculum load of $R$. solani applied in this study might also have contributed to the failure of the BCAs to provide striking disease control.

The BCAs applied during this study did not promote plant growth and grain yield. This is in disagreement with other works which were stating that talc formulations of Trichoderma not only significantly control the sheath blight disease, but also increase the growth and grain yields in the paddy field (Mathivanan et al. 2005; Khan and Sinha, 2007; Soe and De Costa, 2012). Lorito and Woo (2015) stated that although Trichoderma spp. are regarded as plant growth promoting microbes, this property is not present in every strain. It is important to note that in this study, the talc powder inside the formulation formed a white layer on rice leaves, which did not disappear for a long time due to low precipitation. This may negatively affect photosynthesis, respiration and ultimately the plant growth and yield. Consequently, changing the carrier/ bulking agent or reducing the amount of talc powder in the current formulation may result in growth promotion along with an acceptable level of disease control.

In conclusion, findings of the present field study indicate the feasibility of Trichoderma strains for the biocontrol of rice sheath blight disease in the field as an alternative disease control strategy and formulations of $T$. harzianum AS12-2 can be recommended as one of the crop protection strategies for the management of sheath blight. Future research should be directed toward the optimization of the existing formulation, in order that the applied strain can be more capable of becoming established and surviving in the rice phylloplane. This will facilitate the commercialization of the biocontrol Trichoderma strain and the introduction of the resulting biofungicide to the market. Moreover, further experiments are needed to find out the appropriate amount, time and frequency of application.

\section{Acknowledgements}

LK is grantee of the János Bolyai (Hungarian Academy of Sciences) and Bolyai Plus (ÚNKP) Research Scholarships.

\section{References}

Alabouvette C, Olivain C, Steinberg C (2006) Biological control of plant diseases: the European situation. Eur J
Plant Pathol 114:329-341.

Braga GU, Rangel DE, Fernandes ÉK, Flint SD, Roberts DW (2015) Molecular and physiological effects of environmental UV radiation on fungal conidia. Curr Genet 61:405-425.

Burges HD (1998) Formulation of Microbial Biopesticides: Beneficial Microorganisms, Nematodes and Seed Treatments. Kluwer Academic Publishers. The Netherlands.

Chen LH, Zhang J, Shao XH, Wang SS, Miao QS, Mao XY, Zhai YM, She DL (2015) Development and evaluation of Trichoderma asperellum preparation for control of sheath blight of rice (Oryza sativa L.). Biocontrol Sci Technol 25:316-328.

Cumagun CJR, Lapis DB (1993) Practical approach in mass production of Trichoderma spp. as a means of biological control against sheath blight of rice. Philippine Agriculturist 76:251-257.

de França SKS, Cardoso AF, Lustosa DC, Ramos EMLS, de Filippi MCC, da Silva GB (2015) Biocontrol of sheath blight by Trichoderma asperellum in tropical lowland rice. Agron Sustain Dev 35:317-324.

Elad Y, Kirshner B (1993) Survival in the phylloplane of an introduced biocontrol agent (Trichoderma harzianum) and populations of the plant pathogen Botrytis cinerea as modified by abiotic conditions. Phytoparasitica 21:303ロ313.

Elad Y (2000) Biological control of foliar pathogens by means of Trichoderma harzianum and potential modes of action. Crop Protect 19:709-714.

Fravel DR, Larkin RP (1996) Availability and application of biocontrol products. In Canaday $\mathrm{CH}$, ed., Biological and Cultural Tests for Control of Plant Diseases. Vol. 11. APS Press, St. Paul, USA. pp. 1-7.

Freeman S, Minz D, Kolesnik I, Barbul O, Zveibil A, Maymon M, Nitzani Y, Kirshner B, Rav-David D, Bilu A, Dag A, Shafir S, Elad Y (2004) Trichoderma biocontrol of Colletotrichum acutatum and Botrytis cinerea and survival in strawberry. Eur J Plant Pathol 110:361-370.

Gerbore J, Benhamou N, Vallance J, Le Floch G, Grizard D, Regnault-Roger C, Rey P (2014) Biological control of plant pathogens: advantages and limitations seen through the case study of Pythium oligandrum. Environ Sci Pollut Res 21:4847-4860.

Gokulapalan C, Nair MC (1984) Antagonism of a few fungi and bacteria against Rhizoctonia solani. Indian J Microbiol 24:57-58.

Groth DE, Rush MC, Lindberg GD (1990) Foliar fungicides for control of rice diseases in the United States. In Grayson BT, Green MB, Copping LG. Pest Management in Rice. Elsevier, London. pp. 31-52.

IRRI (2002) Standard Evaluation System for Rice. International Rice Research Institute, Los Banos, Philippines.

Jayaprakashvel M, Selvakumar M, Srinivasan K, Ramesh S, Mathivanan N (2010) Control of sheath blight disease in 
rice by thermostable secondary metabolites of Trichothecium roseum MML003. Eur J Plant Pathol 126:229-239.

Khan AA, Sinha AP (2007) Biocontrol potential of Trichoderma species against sheath blight of rice. Indian Phytopathol 60:208-213.

Kredics L, Hatvani L, Naeimi S, Körmöczi P, Manczinger L, Vágvölgyi C (2014) Biodiversity of the genus Hypocrea/Trichoderma in different habitats. In Gupta VK, Schmoll M, Herrera-Estrella A, Upadhyay RS, Druzhinina I, Tuohy M, Eds., Biotechnology and Biology of Trichoderma. Elsevier Science BV, Amsterdam, The Netherlands. pp. 3-24.

Kumar S, Thakur M, Rani A (2014) Trichoderma: Mass production, formulation, quality control, delivery and its scope in commercialization in India for the management of plant diseases. Afr J Agr Res 9:3838-3852.

Latorre BA, Agosin E, San Martín R, Vasquez GS (1997) Effectiveness of conidia of Trichoderma harzianum produced by liquid fermentation against Botrytis bunch rot of table grape in Chile. Crop Protect 16:209-214.

Lo CT, Nelson EB, Hayes CK, Harman GE (1998) Ecological studies of transformed Trichoderma harzianum strain 1295-22 in the rhizosphere and on the phylloplane of creeping bentgrass. Phytopathology 88:129-136.

Lorito M, Woo SL (2015) Trichoderma: A multi-purpose tool for integrated pest management, In: Lugtenberg B (ed), Principles of Plant-Microbe Interactions. Springer International Publishing, pp. 345-353.

Mathivanan N, Prabavathy VR, Murugesan K (2004) Biocontrol potential of microorganisms - an overview: focus on Trichoderma as biofungicide for the management of plant diseases. In Mayee CD, Manoharachary C, Tilak KVBR, Mukadam DS, Despande J, Eds., Biotechnological Approaches for the Integrated Management of Crop Diseases. Daya Publishing House, Delhi, India, pp. 90-108.

Mathivanan N, Prabavathy VR, Vijayanandraj VR (2005) Application of talc formulations of Pseudomonas fluorescens Migula and Trichoderma viride Pers. ex S.F. Gray decrease the sheath blight disease and enhance the plant growth and yield in rice. J Phytopathol 153:697-701.

Mew TW, Rosales AM (1986) Bacterization of rice plants for control of sheath blight caused by Rhizoctonia solani. Phytopathology 76:1260-1264.

Moody SA, Newsham KK, Ayres PG, Paul ND (1999) Variation in the responses of litter and phylloplane fungi to UV-B radiation (290-315 nm). Mycol Res 103:1469-1477.

Naeimi S, Kocsubé S, Antal Z, Okhovvat SM, Javan-Nikkhah M, Vágvölgyi C, Kredics L (2011) Strain-specific SCAR markers for the detection of Trichoderma harzianum AS12-2, a biological control agent against Rhizoctonia solani, the causal agent of rice sheath blight. Acta Biol Hung 62:73-84.
Naeimi S, Okhovvat SM, Javan-Nikkhah M, Kredics L, Khosravi V (2010) Biological control of Rhizoctonia solani AG1-1A, the causal agent of rice sheath blight with Trichoderma strains. Phytopathol Mediterr 49:287-300.

Nagaraju P, Naresh D, Biradar DP, Dronavalli N (2002) Biological control of sheath blight (Rhizoctonia solani) in transplanted rice. Indian J Agr Sci 72:306-307.

Ojiambo PS, Scherm H (2006) Biological and applicationoriented factors influencing plant disease suppression by biological control: a meta-analytical review. Phytopathology 96:1168-1174.

Ou SH (1985) Rice Diseases, $2^{\text {nd }}$ ed. Commonwealth Mycological Institute, Kew, England

Perelló AE, Moreno MV, Mónaco C, Simón MR, Cordo C (2009) Biological control of Septoria tritici blotch on wheat by Trichoderma spp. under field conditions in Argentina. BioControl 54:113-122.

Qin Z, Zhang M (2005) Detection of rice sheath blight for in-season disease management using multispectral remote sensing. Int J Appl Earth Obs Geoinf 7:115-128.

Rabindran R, Vidhyasekaran P (1996) Development of a formulation of Pseudomonas fluorescens PfALR2 for management of rice sheath blight. Crop Protect 15:715-721.

Roy AK (1977) Parasitic activity of Trichoderma viride on the sheath blight fungus of rice (Corticium sasaki). J Plant Dis Protect 84:675-683.

Savazzini F, Longa CMO, Pertot I (2009) Impact of the biocontrol agent Trichoderma atroviride SC1 on soil microbial communities of a vineyard in northern Italy. Soil Biol Biochem 41:1457-1465.

Sehajpal A, Arora S, Kaur P (2009) Evaluation of plant extracts against Rhizoctonia solani causing sheath blight of rice. J Plant Protect Sci 1:25-30.

Soe KT, De Costa DM (2012) Development of a spore-based formulation of microbial pesticides for control of rice sheath blight. Biocontrol Sci Technol 22:633-657.

Stevenson DM, Weimer PJ (2002) Isolation and characterization of a Trichoderma strain capable of fermenting cellulose to ethanol. Appl Microbiol Biotechnol 59:721-726.

Tang Q, Peng S, Buresh RJ, Zou Y, Castilla NP, Mew TW, Zhong X (2007) Rice varietal difference in sheath blight development and its association with yield loss at different levels of N fertilization. Field Crop Res 102:219-227.

Vasantha Devi TV, Malar Vizhi R, Sakthivel N, Gnanamanickam SS (1989) Biological control of sheath blight of rice in India with antagonistic bacteria. Plant Soil 119:325-330.

Woo SL, Ruocco M, Vinale F, Nigro M, Marra R, Lombardi N, Pascale A, Lanzuise S, Manganiello G, Lorito M (2014) Trichoderma-based products and their widespread use in agriculture. Open Mycol J 8:71-126. 
